DOI: https://doi.org/10.31392/NPU-nc.series9.2020.20.03

UDC: 81 '37

\author{
Dasha A. Voronina-Pryhodii \\ National Pedagogical Dragomanov University, \\ Kyiv, Ukraine

\section{COGNITIVE MECHANISMS OF THE TERM'S SEMANTIC DERIVATION}

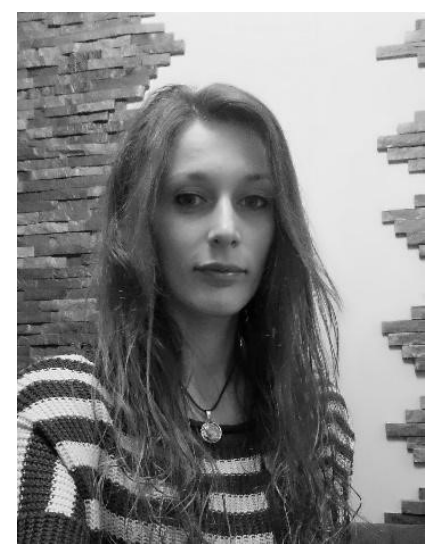

\title{
Bibliographic Description:
}

Voronina-Pryhodii, D. A. (2020). Cognitive Mechanisms of the Term's Semantic Derivation. Scientific Journal of National Pedagogical Dragomanov University. Series 9. Current Trends in Language Development, 20. 33-46. https://doi.org/10.31392/NPUnc.series9.2020.20.03

\begin{abstract}
The article considers the problems of modern terminology in the cognitive aspect, highlights the modern approach to the study of the term as a linguistic sign that represents linguistic, rational and actually special knowledge. The ontological essence of the term is substantiated, which is based on the professional experience of a person's knowledge in a certain professional field. The phenomenon of semantic derivation is characterized as a productive process of replenishment and renewal of the terminological structure of each language. It has been suggested that commonly used words may be subject to semantic shift, acquiring a different semantic, including terminological meaning in order to continue to function within the relevant terminological system. It is proved that terminology is fixed in the narrow professional field of communication, so professional language is the environment of origin, functioning and evolution of special units - terms. Intralinguistic processes of concepts exchange in the process of professional cognition are analyzed, expanding the areas of use of terminological units with a new meaning as a result of semantic derivation. It is established that the main cognitive mechanism of terminologization of commonly used words is the transfer of signs from one area to another, as well as the transfer of terms from one system to another with full or partial rethinking, where semantics are also subject to change, forming a new term.
\end{abstract}

Keywords: terminology, cognitive mechanisms, term, semantic derivation, professional communication.

\section{Introduction.}

At the stage of formation of terminology studies as a science (V. P. Danilenko, H. Felber, V. M. Leichik, D. S. Lotte, A. A. Reformatsky), traditional research delimited and classified the vocabulary according to their areas of use (G. O. Vinokur, T. R. Kiyak), studied the laws of terms functioning and solved problems related to the specific vocabulary of professional languages (L. A. Kapanadze, E. S. Zakirova). Since the efficiency of communication and information exchange processes between scientists and specialists depends on the development of terminology, the key task of terminology science is to 
correlate terms as accurately as possible with elements of thinking and facts of linguistic reality.

According to scientists (B. N. Golovin, R. Yu. Kobrin), terminology studies is a complex scientific discipline at the junction of several branches of knowledge - theoretical and applied linguistics, information retrieval, logic, psychology, specific branches of science and technology. It studies the plan of expression of terms (grammatical organization and laws of functioning), their semantic structure that represents the plan of terms content as carriers of special professional concepts (Golovin, Kobrin, 1987: 8-9).

Terminology is based on semantics, and terms are units that relate language to the real world and represent objects in the real world. Experts use terms to express themselves and exchange views, to organize the structure of their disciplines. The terms can be described in three ways: linguistically, cognitively and communicatively (Cabré, 1999: 39). In other words, through the meaning of the sign we gain access to the semantic system of language. The meanings of individual signs are not separated in the consciousness of the speaker, but form ordered semantic sets together with other meanings.

Many researchers (T. M. Cabré (1999), H. Felber (1980), B. N Golovin (1987), S. V. Grinev (2008), V. M Leichik (2009), N. V Podolskaya (2012), G. Rondeau (1981), J. C. Sagger (1996), A. V. Superanskaya (2012), N. V. Vasilieva (2012), etc) support the status of terminology studies as a complex independent linguistic discipline. A new approach to the study of the term was substantiated in their works by E. I. Golovanova (2011), T. R. Kiyak (2009), J. Lukszyn (2001), O. B. Petrova (2016), M. N Volodina (1995), W. Zmarzer (2001), and others. Regularities of semantic transformations in terminology and in general were considered by A. S. Diakov (2000), Ye. A. Karpilovska (2007), N. F Klimenko (2008), M. P Kochergan (2010), Zh. V. Koloiz (2005), Ye. S Kubryakova (2009), A. Markowski (200), A. A Potebnia (1993), O. O Taranenko (2017), N. P Tropina (2004), L. O. Vakariuk (2010), A. Vezhbytskaya (1996), Ye. S. Zakirova (2013) and others.

Since the semantic structure of terms (and lexical item in general) can be subject to semantic changes depending on cognitive processes and professional and scientific activities, the issue of replenishment and improvement of the terminological structure of the language is relevant.

\section{Aim and Objectives.}

The aim of the article is to characterize the cognitive approach to the study of terminology and its units and to reveal the phenomenon of semantic derivation in terminology.

Achieving this goal involves solving the following objectives:

- to clarify the meaning of the concept of terminology, taking into account the modern cognitive approach;

- to reveal the intralinguistic processes of exchange of concepts and meanings in terminology;

- to investigate the process of semantic derivation;

- substantiate the cognitive mechanisms of semantic derivation.

\section{Methodology.}

The research of terminology and its units is conducted, first of all, within the framework of the terminological direction, where cognitive-semantic aspects of term creation are studied (L. Yu. Buyanova, E. I Golovanova, S. P Khizhnyak, M. N Volodina,). Traditional and modern approaches to the explanation of term-forming processes are compared, revealing the meaning of each of the methods based on changes in semantics. 
The task of cognitive terminology is to analyse the types of professional thinking using appropriate conceptual paradigms, filmed in the form of macro-symbols, i.e. industry terminological vocabulary. This activity is supported by a method of research related to functional terminology, including by separating system-forming terminological series from special vocabulary, establishing different types of synonymous aspects, etc. (Lukszyn, Zmarzer, 2001: 12).

The methods of system-structural description of terms and terminological systems, their conceptual and linguistic characteristics were replaced by methods of cognitive modelling of terminologies and other sets of special units in order to differentiate types and kinds of knowledge transmitted by them, to identify a variety of professional knowledge formats. It gives the terminology studies not descriptive but explanatory character.

Thanks to the methods of analysis and generalization, the idea of terminology in the cognitive aspect was formed, which further allowed to explore ways of creating terms, taking into account the causes and consequences of semantic changes.

\section{Results.}

Each industry terminology is meaningfully and functionally characterized by attachment to the narrow sphere of communication of specialists of this science or practice branch. Only they have a true and deep understanding of the meaning of each term, only experts use the terms very accurately. However, this does not limit the role of specialists, they not only create terms, but also clarify the boundaries of the content of terms, select the most accurate terminological name of the concept among the variants of the name. And this shows two characteristic features of terminology: its attachment to the narrow sphere of communication and conscious participation in the creation and improvement of terms (Danilenko, 1977: 53).

Modern terminology is expanding its research, which now covers not only the term as an object of terminology, but also man and his cognitive activity. At the present stage of formation of the term science, it has become impossible to study ways of linguistic expression of professional concepts without penetrating into their essence. This stage in the development of terminology is called cognitive.

\subsection{Cognitive stage of development of terminology.}

We agree with the opinion of O. B Petrova that "the cognitive approach [...] describes terms (units of terminological systems) in terms of their reflection of the cognition process in general and the creation of fragments of the scientific picture of the world" (Petrova, 2016: 298).

L. L. Nelyubin (Nelyubin, 2003: 65) characterizes cognitive terminology as "a direction in linguistics that studies and describes language in terms of cognitive mechanisms underlying human mental activity". That is, the modern approach complements traditional teachings with a new vector of research of terminologies and their units (terms), taking into account the linguistic and cognitive nature of systemic connections.

If we talk about the difference between the principles and methods of cognitive learning of language from the traditional approach, it is, according to E. I. Golovanova "due to the emphasis on the relationship of language structures with mental structures that reflect the features of human experience and activity, issues of representation in language different types of knowledge - everyday and scientific, associative-image and rational-logical" (Golovanova, 2011: 6). That is, "the language provides the processes of categorization and conceptualization of the world, representing certain conceptual structures at different levels" (Korolyova, 2018: 100).

Order of thought and conceptualization is the cognitive side of terminology; the 
transfer of knowledge is its communicative side. Terminology is the most important characteristic of specialists' communication, because it distinguishes special languages from the general language, as well as special languages from each other. Experts use terminology not only to organize thought, but also to convey specialized knowledge in one or more languages and to structure the information contained in specialized texts (Cabré, 1999: 45).

Recently, the study of terminological issues is receiving attention from scientists, and interest in the study of vocabulary designed to serve special professional areas of communication is growing steadily. Industry terminology occupies a special place in professional communication, where professional information is exchanged.

Today it is generally accepted that each professional field has its own language apparatus, which includes the language tools necessary for the linguistic implementation of the theory and practice of professional knowledge and professional communication. According to T. R Kiyak, linguists count more than 300 professional languages (Kiyak, 2009: 23). In other words, each professional field of scientific knowledge has its own "language for special purposes".

J. Sager defines languages for special purposes as semi-autonomous, complex semiotic systems based on and derived from the national language. According to him, their use requires a special knowledge base and a limited number of specialists, working in a particular field of production (Sagger, 1996: 187).

Professional language is the environment of origin, functioning and evolution of special units - terms, that are the ultimate expression of special thought. H.-R. Fluck is convinced that the number of professional languages corresponds to the number of areas of professional activity, which means not only such complexes as economics or medicine, but also their subsystems, such as finance or anatomy (Fluck, 1996: 16).

E. S Zakirova argues, that "industry terminology is addressed to a certain part of society". According to her, "the result of the development of scientific knowledge, intellectual activity aimed at identifying the results of cognitive activity and familiarity with the basic concepts of a particular industry is the formation of industry terminology as a set of special lexical units designed to nominate certain professional concepts" (Zakirova, 2013: 23).

These special language units, verbalized tools of terminology of various spheres, are terms. The definition of A. V Superanskaya, N. V Podolskaya, N. V Vasilieva combines the views of many researchers, pointing out that "[...] term is a special word (or phrase), which is adopted in professional activities and is used in special conditions; [...] Verbal concept designation of a certain field of professional knowledge; [...] The main conceptual element of a special purpose language. [...] For its correct understanding, the term requires a special definition (exact scientific definition)" (Superanskaya, Podolskaya, Vasilieva, 2012: 14).

In the cognitive aspect, the concept of the term was expanded, and it began to be considered as a constantly changing unit, given its correlation with the process of cognition.

The term is considered not as a static unit, but in terms of its conditionality by the nature of the discourse in which it is used. Each type of discourse imposes its limitations on the form and content of language signs that function in it (Golovanova, 2011: 41). Moreover, "the meaning of a sign-term is determined, on the one hand, by the objective meaning of the corresponding concept, and on the other - by the subjective, conscious principle introduced by the researcher, who defines the content of a special concept nominated by a term" (Danilenko, 1977: 58).

Thus, knowledge is stored in the form of terms, the semantics of which may change in connection with cognitive processes and the scope of language units use. Scientific and cognitive activity leads to the creation of terminological units, forming the structural base of the professional field, which serves as a means of communication, processing and transmission of information between professionals. 


\subsection{Intralingual exchange processes of concepts and meanings in terminology.}

Linguistic units undergo semantic shifts that cause a mismatch between their original meanings and the new concepts they have come to call. In other words, these are terms formed by extending the meaning of existing words. S. V. Grinev-Grinevich argues that a large number of terms are formed by narrowing, specializing the meaning: "the formation of terms by specializing the meaning of existing common words indicates that the relevant terminology begins to stand out from the general language and be understood as a special layer of vocabulary" (Grinev-Grinevich, 2008: 125-127).

However, not all scientists agree with this interpretation. D. S. Lotte emphasizes that in the formation of terms, that are complex words or phrases, specialization is often accompanied by narrowing, expanding or even changing the meaning of one of the terminological elements (or several terminological elements) (Lotte, 1961: 57). That is, in his understanding, specialization as a process is not only a narrowing but also an expansion of meaning.

In turn, S. P. Khyzhniak connects specialization as a method of term formation with rethinking and clarifying the concept: "The considered type of terminological rethinking of common words is based on specialization (clarification) of the meaning of the term" (Khyzhniak, 2016: 104-105).

The next way to create terms is to consider borrowing, but in modern terminological research, there is a different understanding of this phenomenon. Sometimes the term "borrowing" refers to the process of words terminologization of general literary language, or, in some cases, popular speech and slang words (Kapanadze, 1968: 152-153). According to Rondeau's classification (Rondeau, 1981: 129) such borrowings are internal (intralingual), and they, as well as "external" are a source of formation of terms.

Considering the peculiarity of the origin of such terms and their apparent ability to simultaneously serve the commonly used system of literary language and its terminological system, the famous terminologist V. P. Danilenko suggests not to consider such words borrowed from commonly used language, as these terms can "function in two qualities, differing in how the word differs from the term in general" (Danilenko, 1971: 7).

In turn, M. T. Cabré distinguishes three types of borrowings, depending on the code from which the units are borrowed:

- borrowed words from Greek or Latin, which are often called neoclassical borrowings;

- borrowed words from another, modern language, i. e. real borrowings;

- borrowings from other geographical or social dialects or other subject fields from the same language, which are not usually considered borrowings (Cabré, 1999: 88).

However, S. V. Grinev-Grinevich, contrary to the above-mentioned opinion, argues that the difference in content should indicate certain changes in meaning associated with the formation of a special idea or concept, covered by the meaning of the term. That is, we can talk about the independence of terminological meaning, because there are differences in semantic and structural factors, so such terms can naturally be included in the category of terms formed semantically - borrowing from common language (Grinev-Grinevich, 2008: 125).

It is believed that borrowing as a way to create new terms is effective only when the national language of borrowing has its own system of term formation, able to adequately respond to the real needs of professional activity. This means that the terminology system of this language, in addition to its main function, i. e. the creation of new terminological units on a national basis, also has secondary functions. They include: 1) the function of the regulator in the transition of terms from foreign to national terminology; 2) the function of adaptation of foreign terminological units due to their structural properties; 3 ) the function of 
the instrument of harmonization of the national terminological system by adapting the corresponding terminological prototype to the nature of the national language (Lukszyn, Zmarzer, 2001: 76).

V. M. Leichik also considered the transition of a lexical unit from the sphere of nonterms to the sphere of terms as borrowing, but also emphasized the more relevant at that time borrowing of terms - from other terminologies or terminological systems - intersystem borrowing, and distinguished four types:

- borrowing a separate term;

- borrowing fragments of terminology;

- borrowing of all terminology;

- borrowing the principle of construction of terminology (Leichik, 2009: 112-113).

The presence of contacts between different cultures leads to the occurrence of interlingual borrowings, while the links between industries with their own terminology are the cause of borrowings in professional fields. A significant factor in borrowing and active entry of a foreign word into the speech is the communicative relevance of the denoted concept. In a professional environment, interlingual borrowing is correlated with a professional concept that has arisen as a result of purposeful activity. The professional concept should be understood as the structure of knowledge related to the content of professional experience (Golovanova, 2011: 179-181).

D. S. Lotte proposed a classification of borrowed words, dividing them into literal and transformative. He called these two types of borrowings original. By transformational borrowings he meant words or phrases transformed at the time of translation by omitting or adding any element or replacing a complex word with combinations. In contrast, borrowing "in its pure form" is a word transferred to the recipient language in the form in which it exists in the producer language (Lotte, 1982: 10-14).

From a cognitive standpoint, interlingual borrowing should be interpreted as the interaction of two conceptual spaces, which results in a borrowed concept or conceptual structure. In contrast to the original (indigenous) concepts, which naturally arise within national cultures and are fixed by appropriate linguistic means, borrowed concepts are perceived in the process of contact with other cultures and their verbalization is carried out by foreign means. Thus, E. I. Golovanova proposes to use the term "conceptual alignment" to adequately describe and explain the process of interlingual borrowing in the professional spheres of language. "At the linguistic level, conceptual alignment is manifested in the presence of relative lexical series, chains and paradigms that reflect knowledge and experience in certain areas of activity" (Golovanova, 2011: 181-182).

To facilitate the international communication of specialists, there is an internationalization of terms. Internationalisms are the same or similar in form and similar in meaning to the terms used in several (at least three) national languages (Grinev-Grinevich, 2008: 161). They successfully serve international needs in certain areas of professional (and not only) activities without obvious difficulties in understanding the concepts.

International terms in the terminological system appear in two different formats. In the first format, the lexical unit is taken from world languages and adapted to the native language. In the second - the unit is based on classical languages. Such a linguistic unit retains the status of internationalism even when it was created and operates in only one terminological system. This is due to the fact, that it is understandable for the foreign language professional environment, thus characterizing the current state of terminology in this field of knowledge (Lukszyn, Zmarzer, 2001: 71). This fact has serious consequences in the language policy of individual countries, and in the organization of the necessary terminological services. 
If we talk about the presence of common elements (in particular, lexical) in two not necessarily related languages, it is worth distinguishing such a concept as "linguistic parallels". Linguistic parallels can be random (caused by a random consonance of words) and regular (caused by the conscious borrowing of lexical elements in one language from another) (Dubichinskii, 1995: 26).

According to scholars, there are three types of lexical parallels (given the degree of discrepancy between the meanings of borrowed words): 1) complete internationalisms, i.e. words that completely coincide in all meanings in languages; 2) partial internationalisms, i.e. words, which meanings coincide only partially; 3) pseudo-internationalisms, the meanings of which in these languages do not coincide at all (Diakov, Kiyak, Kudelko, 2000: 125).

Linguistic parallels arise in scientific and technical terminology, because the term formation is borrowing elements of foreign origin. According to E. F. Skorokhodko we define the following types of correspondences of lexical parallels in national terminological systems:

- the foreign term and the native language term are absolute equivalents ((English) airplane - (Ukrainian) аероплан; (English) biology - (Ukrainian) біологія);

- the term native language is the relative equivalent of a foreign one (bulldoser бульдозер з неповоротним відвалом);

- the term of the native language is a partial equivalent of a foreign one;

- the term of the native language is a partial relative equivalent (terms of two languages express intersecting concepts) (Skorokhodko, 1963: 82).

Some internationalisms can penetrate from the spheres of professional communication to general use, and, as a result, be endowed with additional cultural meanings. In this case, we can distinguish "ideal internationalisms" that everyone will understand, even if they do not speak foreign languages or are not experts in a particular field - the main requirement for an ideal international form is absolutely identical meanings in different languages (Felber, 1980: 75).

\subsection{The phenomenon of semantic derivation in cognitive terminology.}

Given the fact that the terminology of various fields is supplemented by new terms, it is necessary to distinguish between studies of intra-industry lexical units and the study of their semantics, given the modern cognitive approach. Thus, the mechanisms of the transition of thought to verbal notation, the embodiment of thought in the word are considered in the problem framework of the term motivation and the related problem of its internal form.

E. I Golovanova explains that 'the term as a linguistic sign accumulates knowledge of three types: linguistic (which is the result of everyday knowledge), rational (rational-logical, encyclopedic, scientific - in a broad sense) and actually special (based on professional experience and arose as a result of professional knowledge). Thus, each of the types of knowledge represented in the term as a linguistic sign is based on a certain experience of human interaction with the world" (Golovanova, 2011: 70). Moreover, the changes that occur in the composition of industry terminology reflect changes in the content of concepts, which in turn indicate the degree of study of a phenomenon, the object of reality (Danilenko, 1977: 52).

According to A. Vezhbitskaya, language serves to express meaning and, as a consequence, it is in this feature it (language) should be considered. The only question is how to describe these values (Vezhbitskaya, 1996: 5).

The development of terminology is closely related to the development of the process of cognition in the relevant scientific field, where scientific knowledge is formed and accumulated in the process of linguistic and mental cognitive activity of man. The occurrence of new scientific concepts involves the search for the most successful verbal expression of these concepts. Term formation is always a conscious process of 
comprehension. According to G. O. Vinokur, "terms do not appear, but are invented, created as they become aware of their necessity" (Vinokur, 1939: 24).

Relevant A. Vezhbitskaya opinion, that "each language creates its own "semantic universe" [...] and not only thoughts can be "thought" in one language, but also feelings can be felt within one language consciousness, but not another" (Vezhbitskaya, 1996: 21). Therefore, it is possible to distinguish not only national languages, but also industry languages, which separate special terminologies are subordinated to. For example, first of all chemical terminology is possessed by specialists in the field of chemistry, medical - in the field of medicine, legal - in jurisprudence. These are the individual "universes" that experts learn on the theoretical and practical levels, verbalizing their knowledge in the form of special lexical units in order to communicate and transmit information to each other.

Since terms are the core of industry languages (languages for special purposes), they serve as the main means of conceptual orientation in the cognitive-communicative space, set the direction of mental activity of professionals, serve as a reference point and a reference point (Golovanova, 2011: 78).

Terminology of any field of knowledge or activity is the main means of storage, processing, translation and development of conceptual paradigms in science, so 'the study of semantics of language units, objectifies concepts, allows access to the content of concepts as mental units' (Popova, Sternin, 2007: 14). A concept is an affiliation of human consciousness, a global unit of mental activity, and an ordered set of concepts in human consciousness forms its conceptosphere.

The modelling function of terminological units is associated with the emergence of new concepts on the basis of existing ones due to the convergence of related concepts, establishing an analogy between them (Golovanova, 2011: 22).

Human knowledge, which structures the concept of the scientific picture of the world, in the most generalized form is represented as a systematically organized set of concepts and relationships between them. Given the fact that the concept of the scientific picture of the world corresponds to the linguistic model of existence and that concepts are expressed in language through terms, priority should be given to systematic research of the emergence, evolution, modification, assimilation and modeling of scientific knowledge at the level of terminological spaces (systems, fields, tiers) (Buyanova, 2016: 11).

Whereas structural knowledge is interrelated with their linguistic expression, scholars continue to search for the semantic content of existing linguistic units. The phenomenon of semantic derivation is actualized in modern scientific works, as it is a productive way to update the composition of language. Thus, commonly used words acquire new meanings and are able to "migrate" into the appropriate terminology, within which they are functioning as terms. Since there are other terms to denote this phenomenon: neosemanticization, semantic (lexico-semantic) derivation, secondary (terminological) nomination, semantic (lexicosemantic) way of creation, consider the interpretation of these concepts by other scholars.

Semantic derivation is considered as "a complex multifaceted process of creating new meanings of words, which causes a restructuring of the words semantic structure and affects the entire lexical-semantic system of language. This makes it dynamic, reacting quickly to changes in extralingual reality, reflecting them" (Tropina, 2004: 28).

According to $\mathrm{Zh}$. V Koloiz, lexical and semantic derivations are types of nominative derivation, as "the product of lexical derivational processes differs from its derivational base in both form and content, while semantic derivation leads to a change only in content" (Koloiz, 2005: 8). Only the content changes, the material shell acquires a different meaning, which is tested by the practice of language use.

In linguistics, semantic (lexico-semantic) is a way of creating new words, in which the 
sound shell of the formative word remains unchanged, but acquires a new meaning, and the formative word is thus transformed into a derivative (Vakariuk, 2010: 188). That is, when creating words in a lexical-semantic way, no special word-forming means are used, only the semantics change. Ukrainian scholar I. I. Kovalyk argues that "the lexical-semantic way is a load of new lexical meaning of the word that exists in this language, while preserving most of the original meaning of the word" (Kovalyk, 1961: 51). Thus, one word accumulates a different number of meanings that do not replace each other, but are added to the main (perhaps most commonly used) interpretation.

The linguistic image of an object is multidimensional, i.e. it combines several ideas about this object. Interpretation of the subject name contains comprehensive information about this concept, as accurately as possible reflecting its essence and functioning in the relevant field. According to V. M Teliya, the secondary nomination is formed on the basis of the meaning of the word whose name is used in the new naming function (Teliya, 2002: 336). Moreover, the terminological nomination is always secondary to the general nomination, because the key task of such term formation is to reflect the acquired knowledge with the help of a language sign, not overloading with unnecessary vocabulary, but fully covering all possible meanings and understandings embedded in this concept. Any human activity is mediated by language, and, consequently, the verbalization of concepts is a reflection of the result of such activities. The name given to the new concept reflects the features that are basic in a particular area of subject knowledge, i.e. the term is a combination of adequate external form and pronounced conceptual content.

From a cognitive point of view, M. N. Volodina argues that "terminological nomination is not only a process of designation and communication, but also a process of cognition. The structure of names is based on the correspondence of information and its linguistic form, as well as on the identity of reality reflections in human consciousness" (Volodina, 1995: 81).

Regarding neosemanticization as a process of term formation, there are controversial issues in relation to the interpretation of its meaning. Scholars consider neosemantisms to be "foreign lexical items recorded in dictionaries of foreign words that have become used with new meanings, either as a result of the use of terminological vocabulary in another terminology or in commonly used vocabulary". Neosemantisms acquire expressiveevaluative meaning or metaphorical use (Klymenko, Karpilovska, Kysliuk, 2008: 383).

Researchers (Zh. V. Koloiz, N. Z. Kotelova, D. V. Mazuryk) claim that semantic derivation - replenishment of an already existing word with a new semantic meaning - is a kind of neologism. As an example, N. Z Kotelova emphasizes that "the concept of neologism, in accordance with the internal form and etymology of this term, refers to a unit of vocabulary, words. Naturally, it covers a new meaning of the word (lexical-semantic variant of the word), is also a new lexical item; sometimes it is called a semantic neologism" (Kotelova, 2015: 191).

However, scholars express a different opinion about neosemanticization (H. Kurkowska, A. Markowski). They see it as borrowing - a lexical-semantic way of creating terms, in which lexical units are transferred from one language to another. Polish researcher A. Markowski uses the following terms to denote this kind of neosemantism: ukryte zapożyczenie - hidden borrowing, "obcysemantyzm" - "foreign semantism", "inosemantism". Since the main source of origin is considered to be mainly English, he also singles out the term "anglosemantyzm" (Markowski, 2000: 102).

Changing the scope of terms functioning also leads to the occurrence of neosemanticism, the so-called neo-borrowing, because in the process of cognition there are intralinguistic processes of exchange of concepts and meanings, thereby expanding the use of 
terminological units with new content.

Due to the tendencies to language economy, there are processes of acquiring new meaning in borrowed lexical items. Ye. A. Karpilovska explains these phenomena as follows: "In fact, it is difficult to determine whether a new meaning is re-borrowed in a previously borrowed word (often from another language), or a new meaning develops on the basis of the semantics of the borrowed word, but in Ukrainian" (Karpilovska, 2007: 82). Therefore, the researcher distinguishes repeated and hidden borrowings. In the repeated new meaning does not develop from the previously borrowed, and in the hidden new meanings can develop on Ukrainian language basis. The latter are also called semantic calque, neosemantisms.

Thus, scholars consider neosemantism under the prism of two interpretations simultaneously and classify it into two types: 1) as a kind of neologism, a consequence of semantic word formation within an already known unit or existing in the language of the formal structure; 2) as a kind of neo-borrowing-meaning within the existing unit in the lexicon with a different meaning (Klymenko, Karpilovska, Kysliuk, 2008: 38).

Analysing the works of other researchers, we find a classification that distinguishes between the concepts of neosemanticization and neologization (J. Lukszyn and W. Zmarzer). They argue that the new units within the terminological system due to the way they are created form several groups: 1) neosemantism; 2) neologisms; 3) borrowing; 4) internationalisms.

Neosemantisms arose as a result of the figurative use of words of the national language (commonly used). This phenomenon is called "terminologisation" or "semantic derivation". This group also includes neosemantisms, which arose as a result of the terms use of one terminological system within another, acquiring a new meaning, but retaining its original semantic clarity. This process is called "transterminologization" (Lukszyn, Zmarzer, 2001: 77).

Summarizing the above-mentioned, we distinguish the following components of semantic derivation:

- terminologisation, i.e. the transition of a commonly used word to the classification of "term", in the process of which the semantics undergoes appropriate changes;

- transterminologisation, where the term of one professional field acquires a new meaning in another field and becomes part of its terminology.

\subsection{Cognitive mechanisms of semantic derivation.}

The mechanism of transterminologization includes, first of all, semantic processes. The lexical unit begins to denote a general (abstract or specific) concept that is part of the concepts system of a particular special field of knowledge and (or) activities. Further, the meaning (concept) assigned to the lexical unit is separated from all other meanings of this unit. Finally, in some cases, the lexical unit involved in the language for special purposes (LSP) acquires such word-forming and grammatical features that are necessary to denote specific concepts in this area (Leichik, 2009: 80).

A. V. Superanskaya notes that terminology is, "figuratively speaking, semantic conversion". Semantic conversion is bordered by terminological conversion transterminologization - "transfer of a ready term from one discipline to another with its full or partial rethinking and transformation into an intersectoral homonym" (Superanskaya, Podolskaya, Vasilieva, 2012: 194). In this case, it can be transferred from one term system to another as a separate term and terminological block, which includes concepts related to the central term (ibid: 203).

Considering the cognitive aspect, we understand that the terminology of national words determines the viability of the national language as a tool for collecting, storing and obtaining professional knowledge. This process also has a social basis. The words of the 
national language, which have been adapted to the terminological system, combine general knowledge of the language and professional knowledge. That is, "terminological neosemantism, due to its primary meaning, which is ultimately the basis of semantic derivation, usually has a clear semantic structure, i.e. it is a correctly oriented term" (Lukszyn, Zmarzer, 2001: 78).

The dynamic nature of terminological systems was considered from different angles in "traditional terminology". Thus, A. A. Reformatsky noted the dynamics of the processes of terminology of general literary words and determinologization: "The field of terminology, on the one hand, is closed, on the other - is in continuous interaction with everyday language. Any everyday non-official word can become a term by including it in a special dictionary on the basis of exact correspondence with a certain socially organized concept. On the other hand, any term can return to everyday language by losing its exact correspondence with the named concept" (Reformatsky, 1986: 164). V. M. Leichik also singles out the process of determinologization, "when the lexical unit used as a function of a term in the terminology system ceases to be so. Determinologization can occur in cases where a theory is considered incorrect, and the terms that denote its concepts are out of scientific use" (Leichik, 2009: 29).

According to scientists, determinologizatsiya has two stages: 1) the entry of the term as a word with terminological meaning in the general language; 2) transfer of the meaning of this "terminological" word already in the general language and the occurrence (often in a metaphorical way) of an everyday word on its basis (Superanskaya, Podolskaya, Vasilieva, 2012: 134).

Researchers of the sublanguages of science and technology note a tendency to systematic selection of words from commonly used. According to F. A. Citkina, "the semantic way of forming terms from common words is often based on narrowing or metaphorical transfers, i.e. on the similarity of function, form, purpose, process, quantitative feature, origin, appearance, relationship of components, adjacency of concepts, often in a combination of these features" (Citkina, 1988: 46).

Semantic derivation is the result of mechanisms of metaphorization and metonymic transference. The metaphorization of the meaning of commonly used lexical items usually occurs first on the basis of external similarity, and later - on the basis of similarity of functions of the named objects. For example, clutch lock, pump collar, rock skeleton.

The cognitive specificity of metaphor in terminological systems was successfully noticed by the authors of the work "General Terminology", who summarized the results of terminological work from the 30's of the twentieth century. until the end of the 80's (Superanskaya, Podolskaya, Vasilieva, 2012: 91-95). They write: "The term is fundamentally outside the emotional plane. Therefore, imagery can be used in a terminological nomination to specifically motivate a term, to demonstrate its relationship to other terms, and to name things with each other. Thus, what normally serves to create stylistic figures is used in a special nomination to create terms" (ibid: 93).

Metaphorical thinking leads to an understanding of a new fact, situation, process, or any type of category based on an imaginary analogy between what one is trying to understand and what one already knows and understands. This inventive or creative ability is important in neolexicalization and is directly involved in this process (Temmerman, 2000: 182). That is, figurative thinking, the result of which is the metaphorical naming of new categories with existing lexical items, leaves its mark in human experience. The cognitive mechanism of metaphorization is based on the understanding of abstract phenomena and entities through the known and the ordinary (Golovanova, 2011: 17). In other words, semantic transfer occurs from a specific, sensory and therefore more familiar area (basic knowledge) to a more abstract and less familiar. 
When creating terms, metonymic transfer is also used, which occurs not on the basis of similarity of external or internal features of the previous and present subject, but on the basis of their adjacency, their tangibility in space or time. This changes not only the subject, but also the concept as a whole (Reformatsky, 2004: 86). Under the metonymy B. M Golovin and R. Yu. Kobrin understand "the transfer of the name of one object to another object, which is in the associative relations with the first, part - whole, genus - species" (Golovin, Kobrin, 1987: 49). For example, building - an action ») building, house - result of an action; cabling - action ») cabling as a cable network - result of action; canalization - construction of channels (action) \)> system of channels (result of action).

According to E. I. Golovanova, metaphor is an actual mechanism at the stage of initial professional knowledge (as well as in the field of abstract scientific knowledge, where this form of thinking is used to comprehend complex objects), it is based on the operation of comparison, and the result is finding analogies between objects and phenomena. then metonymy acts as a mechanism of "advanced" professional knowledge. Deepening in the understanding of the connections between the objects of professional space and the distinction between different types of professional knowledge, metonymy becomes the most significant (Golovanova, 2011: 114).

Thus, metonymy together with metaphor is considered as one of the improving ways of living space and as the most important source of mental processes within individual and collective self-consciousness.

\section{Conclusions.}

The cognitive approach to the study of terminology and its units opens up new possibilities for explaining fixative observations and facts, as well as through which mental structures reflect professional experience. Human mental and cognitive activity occupies a key position in the process of creating new terminological units within a particular industry for the transfer of specialized knowledge and their subsequent exchange. There was an expansion of the concept of the term, which became a verbalized tool in various fields. Based on the considered definitions of this concept, we can generalize that the term is a key unit of science, special fields of knowledge and areas of human activity, which serves to nominate objects and processes and at the same time is a means of learning about the world.

The cognitive approach to the study of the process of semantic derivation substantiates and explains the mechanisms of metaphorization and metonymic transference, where the concept plays a key role. It is believed that the sources of formation of new scientific terms are common vocabulary, terminology of existing areas of knowledge and areas of human activity, as well as terminological systems of languages for special purposes.

The semantic structure represents a plan of the content of terms as carriers of special professional concepts, therefore the prospects of further research should include the substantiation of cognitive-semantic mechanisms in the process of creating terms within the sphere of production activity.

\section{References}

Buyanova, L. Yu. (2016) Terminologicheskaya derivaciya $v$ yazyke nauki: kognitivnost', semiotichnost', funkcional'nost' [Terminological derivation in the language of science: cognition, semiotics, functionality]: monografiya (4-e izd., stereotip). FLINTA.

Cabré, T. M. (1999). Terminology. Theory, methods and applications (DeCesaris, J. A., Trans.). John Benjamins B. V.

Citkina, F. A. (1988). Terminologiya $i$ perevod ( $k$ osnovam sopostavitel'nogo terminovedeniya) [Terminology and translation (to the basics of comparative terminology)]: monografiya. Izd-vo pri L`vovskom gos. un-te izdat. obedineniya "Vishha shkola".

Danilenko, V. P. (1971). Leksiko-semanticheskie i grammaticheskie osobennosti slov-terminov 
[Lexico-semantic and grammatical features of word-terms]. Issledovaniya po russkoj terminologii [Studies in Russian terminology]. Nauka, 7-67.

Danilenko, V. P. (1977). Russkaya terminologiya: Opyt lingvisticheskogo opisaniya [Russian Terminology: An Experience of Linguistic Description]. Nauka.

Diakov, A. S., Kiyak, T. R., \& Kudelko, Z. B. (2000). Osnovy terminotvorennia: Semantychni ta sotsiolingvistychni aspekty [Fundamentals of Terminology: Semantic and Sociolinguistic Aspects]. Vyd. dim "KM Academia".

Dubichinskij, V. V. (1995). Teoreticheskoe i leksikograficheskoe opisanie leksicheskix parallelej [Theoretical and lexicographic description of lexical parallels]. Thesis' Abstract.

Felber, H. (1980). International Standardization of Terminology. International Journal of Sociology of Language, 23 (Standardization of Nomenclature), 67-80.

Fluck, H.-R. (1996). Fachsprachen: Einführung und Bibliographie. Francke.

Golovanova, E. I. (2011). Vvedenie $v$ kognitivnoe terminovedenie [Introduction to Cognitive Terminology]. Nauka.

Golovin, B. N., \& Kobrin, R. Yu. (1987). Lingvisticheskie osnovy ucheniya o terminah [Linguistic basis of the doctrine of terms]. Vysshaya shkola.

Grinev-Grinevich, S. V. (2008). Terminovedenie [Terminology]. Akademiya.

Kapanadze L. A. (1968). Osobennosti nominacii v oblasti nauchno-texnicheskoj terminologii. Funkcionirovanie terminov nauki i texniki $\mathrm{v}$ obshheliteraturnom yazy 'ke XX veka [Features of the nomination in the field of scientific and technical terminology. Functioning of the terms of science and technology in the general literary language of the XX century]. Russkij yazy`k $i$ sovetskoe obshhestvo. Leksika sovremennogo russkogo literaturnogo yazy ka. Nauka, 151-185.

Karpilovska Ye. A. (2007). Tendentsii zasvoiennia anhlitsyzmiv u suchasnii ukrainskii movi [Trends in the assimilation of English in the modern Ukrainian language]. Visnyk Kyivskoho natsionalnoho linhvistychnoho universytetu. Seriia Filologia, 10(2), 78-84.

Khizhniak, S. P. (2016). Kognitivnaya problematika v obshhej teorii termina [Cognitive problems in the general theory of the term]. ICz "Nauka".

Kiyak, T. R. (2009). Lingvistika professionalnyx yazykov i terminovedenie [Linguistics of professional languages and terminology]. Terminologiya $i$ znanie: materialy I Mezhdunar. Simpoziuma, Institut russkogo yazyka im. V. V. Vinogradova RAN, 21-27.

Klymenko, N. F., Karpilovska, Ye. A. \& Kysliuk, L. P. (2008). Dynamichni protsesy v suchasnomu ukrainskomu leksykoni [Dynamic processes in the modern Ukrainian lexicon]. Vydavnychyi Dim Dmytra Buraho.

Koloiz, Zh. V. (2005). Semantychni neolohizmy yak rezultat semantychnoi deryvatsii [Semantic neologisms as a result of semantic derivation]. Visnyk Khark. nats. un-t im. V. N. Karazina. Seriia Filolohiia, 659(44), 6-11.

Korolyova, A. V. (2018). Combinatorial Syntagmatics: from the Theory of Valency to the Theory of Conceptual Integration. Scientific Journal of National Pedagogical Dragomanov University. Series 9. Current Trends in Language Development, 17. 99-111. https://doi.org/10.31392/NPU $\square$ nc.series9.2018.17.08

Kotelova, N. Z. (2015). Izbranny`e raboty`. Rossijskaya akademiya nauk; Institut lingvisticheskix issledovanij [Selected works / Russian Academy of Sciences; Institute for Linguistic Research]. Nestor-Istoriya.

Kovalyk, I. I. (1961). Vchennia pro slovotvir: slovotvorcha kharakterystyka slova : vidnoshennia vchennia pro slovotvir do inshykh movoznavchykh dystsyplin [The doctrine of word formation: wordformation characteristic of the word: the relation of the doctrine of word formation to other linguistic disciplines]. LDU.

Leichik V. M. (2009). Terminovedenie: Predmet, metody', struktura [Terminology: Subject, methods, structure]; izd. 4-e. Knizhnyj dom "LIBROKOM".

Lotte D. S. (1982). Voprosy zaimstvovaniya $i$ uporyadocheniya inoyazychnyx terminov $i$ terminoelsmentov [Issues of borrowing and ordering of foreign language terms and terminology]. Nauka.

Lotte, D. S. (1961). Osnovy postroeniya nauchno-tekhnicheskoj terminologii: Voprosy teorii $i$ metodiki [Fundamentals of building scientific and technical terminology: Issues of theory and methodology]. Izd-vo AN SSSR.

Lukszyn J. \& Zmarzer. W. (2001). Teoretyczne podstawy terminologii. Warszawa.

Markowski A. (2000). Jawne i ukryte nowsze zapożyczenia leksykalne w mediach. Język w mediach masowych. Pod red. J. Bralczyka, K. Mosiołek-Kłosińskiej. Upowszechnianie Nauki-Oświata “UN-O”, 96-111.

Nelyubin, L. L. (2003). Tolkovyj perevodovedcheskij slovar [Explanatory translation dictionary]. 3-e izd., pererab. Flinta: Nauka.

Petrova, O. B. (2016). Linhvokohnityvnyi analiz konkretnohaluzevykh terminolohichnykh system [Linguocognitive analysis of specific sectoral terminological systems]. Materialy XXVI Mizhnarodnoi 
naukovo-praktychnoi internetkonferentsii "Problemy ta perspektyvy rozvytku nauky na pochatku tretoho tysiacholittia u krainakh Yevropy ta Azii" (30-31 travnia 2016 r.). Pereiaslav-Khmelnytskyi, 298-300.

Popova, Z. D. \& Sternin I. A. (2007). Semantiko-kognitivnyj analiz yazyka [Semantic-cognitive analysis of language]. Izd-vo "Istoki".

Reformatsky, A. A. (1986). Mysli o terminologii [Thoughts on terminology]. Sovremennye problemy russkoj terminologii. Nauka, 163-198.

Reformatsky, A. A. (2004). Vvedenie v yazykovedenie [Introduction to linguistics]. Aspekt Press.

Rondeau, G. (1981). Introduction à la Terminologie. Centre educatif et culturel inc.

Sagger, J. C. (1996). Terminology, LSP and Translation. John Benjamins.

Skorokhodko, E. F. (1963). Voprosy perevoda aiglijskoj nauchno-texnicheskoj literatury [Questions of translation of the Aiglian scientific and technical literature]. Izd-vo Kievskogo universiteta.

Superanskaya, A. V., Podolskaya, N. V., \& Vasileva, N. V. (2012). Obshchaya terminologiya: Voprosy teorii [General terminology: theory issues]. In T. L. Kandelaki (Eds.). (6th ed.). Moscow: LIBROKOM.

Teliya, V. N. (2002). Nominaciya [Nomination]. In V. N. Yarceva (Eds.), Lingvisticheskij enciklopedicheskij slovar [Linguistic Encyclopedic Dictionary] (2nd ed., pp. 336-337). Bolshaya Rossijskaya enciklopediya.

Temmerman, R. (2000). Towards New Ways of Terminology Description. The sociocognitive approach.

Tropina, N. P. (2004). Semantychna deryvatsiia v suchasnii rosiiskii movi [Semantic derivation in the modern Russian language]. Thesis' Abstract.

Vakariuk L. O. \& Pantso S. Ye. (2010). Ukrainska mova. Morfemika i slovotvir [Ukrainian language. Morphemics and word formation]. Navchalna knyha - Bohdan.

Vezhbiczkaya A. (1996). Yazyk. Kultura. Poznaie [Language. Culture. Cognition]. Per. s angl. Otv. red. M. A. Krongauz, Vstup. st. E. V. Pallchevoj. Russkie slovari.

Vinokur, G. O. (1939). O nekotoryx yavleniyax slovoobrazovaniya $\mathrm{v}$ russkoj texnicheskoj terminologii [On some phenomena of word formation in Russian technical terminology]. Trudy Moskovskogo instituta istorii, filosofii i literatury, 5, 3-54.

Volodina, M. N. (1995). Strukturno-kognitivnyj aspekt terminologicheskoj nominacii [Structural and cognitive aspect of terminological nomination]. Terminovedenie, 2-3, 81-82.

Zakirova E. S. (2013). Nekotorye voprosy terminovedeniya i terminografii kak komponentov obshhej teorii yazyka dlya special'ny' $x$ celej (YaSCz, LSP) [Some questions of terminology and terminography as components of the general theory of language for special purposes (YSC, LSP)]. Izvestiya MGTU "MAMI", 1(15), 6, 20-26.

\section{Бібліографічний опис:}

Вороніна-Пригодій, Д. А. (2020). Когнітивні механізми семантичної деривації терміна. Науковий часопис Національного педагогічного університету імені М. П. Арагоманова. $\quad$ Серія 9. Сучасні тенденцї https://doi.org/10.31392/NPU-nc.series9.2020.20.03

\section{Анотація}

У статті розглянуто проблематику сучасного термінознавства у когнітивному аспекті, висвітлено сучасний підхід до вивчення терміна як мовного знака, що репрезентує мовні, рачіональні та власне спеціальні знання. Обтрунтовано онтологічну сутність терміна, в основі якої лежить професійний досвід пізнання людиною певної фахової сфери. Схарактеризовано явище семантичної деривачії як продуктивний прочес поповнення та оновлення термінологічного складу кожної мови. Зроблено припущення про те, що загальновживані слова можуть підлягати семантичним зрушенням, набуваючи іншого семантичного, зокрема й термінологічного значення з метою подальшого функиіонування в межах відповідної термінологічної системи. Доведено, що термінологія закріплена за вузькою фаховою сферою спілкування, тому професійна мова є середовищем виникнення, функиіонування та еволючії спеціальних одиниџь - термінів. Проаналізовано внутрішньомовні прочеси обміну поняттями у процесі професійного пізнання, розширюючи зони використання термінологічних одиниць з новим значенням як результат семантичної деривації. Установлено, що основним когнітивним механізмом термінологізації загальновживаних слів є перенесення знаків однієї сфери в іншу, а також перенесення термінів із однієї системи в іншу з повним або частковим переосмисленням, де семантика також підлягає змінам, формуючи нове наповнення терміна.

Ключові слова: термінознавство, когнітивні механізми, термін, семантична деривація, професійна комунікаиія. 